\title{
EVALUATION OF ECOREGION-BASED VOLUME EQUATIONS FOR SCOTS PINE (PINUS SYLVESTRIX) IN THE EASTERN DAXING'AN MOUNTAINS, NORTHEAST CHINA
}

\author{
Mbangilwa, M. M. ${ }^{1}-$ He, P. ${ }^{1}-$ JiAng, L. C. ${ }^{1 *}$ \\ ${ }^{1}$ Key Laboratory of Sustainable Forest Ecosystem Management-Ministry of Education, School \\ of Forestry, Northeast Forestry University, Harbin 150040, China \\ *Corresponding author \\ e-mail: jlichun@nefu.edu.cn \\ (Received $13^{\text {th }}$ Dec 2019; accepted $6^{\text {th }}$ May 2020)
}

\begin{abstract}
In this research total volume equations were developed for Scots pine (Pinus sylvestris var. mongolica) in Northeast China. Eighteen total volume equations were fitted to volumes from Forest Inventory Analysis data of the Eastern Daxing'an Mountains in Northest China. Eight ecoregions including: Xinlin (XL), Tahe (TH), Huzhong (HZ), Shibazhan (SBZ), Hanjiayuan (HJY), Xilinji (XLJ), Tuqiang (TQ), Amuer (AME) belonging to two regions including: The northwest of the northern slope of Yilehuli Mountains (NWYLHLM) and The southeast of the northern slope of Yilehuli Mountains (SAYLHLM) were identified and the best volume equations were tested to determine if the differences between ecoregions were statistically significant. Results varied by ecoregion. Average bias prediction error ranged from $-1.2 \%$ to $7.5 \%$ in $\mathrm{XL}$, from $-0.8 \%$ to $11.7 \%$ in $\mathrm{TH}$, from $-13.9 \%$ to $0.08 \%$ in $\mathrm{HZ}$, from $3.5 \%$ to $10.3 \%$ in SBZ, from $-8.9 \%$ to $0.9 \%$ in HJY, from $-2.5 \%$ to $10.4 \%$ in XLJ, from $-11.6 \%$ to $9.4 \%$ in TQ and from $-11.7 \%$ to $1.5 \%$ in AME. However, the ecoregion-based volume equation developed in this study could provide more accurate information on tree growth and development of forest ecosystems to managers and planners.
\end{abstract}

Keywords: conifer species, prediction error, ecoregion, total volume, forest management

\section{Introduction}

Northeastern China is divided into four vegetation regions which include cold-temperate deciduous coniferous forest region, the temperate mixed evergreen coniferous-deciduous broad-leaved forest region, the warm temperate deciduous broad-leaved forest region, and the temperate steppe region (Qian, 2003). Temperate coniferous forests are geographically and taxonomically diverse, found on five continents (North America, Europe, Asia, South America and Africa) (Frelich, 2016). The latter constitute a type of terrestrial habitat defined by the World Wildlife Fund (WWF, 2012, 2019). Temperate coniferous forests are found predominantly in areas with warm summers and cool winters, and vary in their kinds of plant life. These forests are common in the coastal areas of regions that have mild winters and heavy rainfall, or inland in drier climates or mountainous areas. Many species of trees inhabit these forests including pine (Mongolian Scots pine), cedar, fir, and redwood (WWF, 2012, 2019) including the giant sequoia and the coastal sequoia (large known trees) in California and Fitzroya which live more than three thousand years in Chile (Frelich, 2016).

Mongolian Scots pine (Pinus sylvestris var. mongolica) is one of the major tree species in the network of Three-North Shelterbelt for windbreak and sand stabilisation in China (Wang et al., 2012). It is a geographic variety of Scots pine (P. sylvestris) and is widely distributed in northern China (Wang et al., 2017). It is considered as a crucial 
ecological species in northern China, especially in sandy areas, due to its great adaptability to infertile soils and cold and arid habitats (Han et al., 1998; Wang et al., 2017). Its natural distribution is mainly located in the sandy soils of northeast China. Since it has high tolerance to cold, drought, soil infertility and grows naturally in the sandy land, this species had been introduced to the edge of sandy lands in northern China to protect nearby lands from moving sand dunes since the 1950s (Wang et al., 2012). Since its wind-sheltering functions are strongly correlated with the architecture and ecophysiological processes of each tree, the model-assisted analysis of the cover architecture and the functional dynamics of the Mongolian Scots pine would be useful to better understand its structure role and behavior in windbreak ecosystems of arid and semi-arid regions in China (Wang et al., 2012). For this investigation, we present a study of the model of Volume Equations based on Scots pine ecoregions in northeastern China.

Volume is referred to quantity and it is the common widely used measure of wood quantity in forest mensuration. Total stem volume equations are the commonly used tools in quantifying timber stocks (García-Espinoza et al., 2018). According to Li (2019), surveying is the determination of the diameters, heights or volumes of a standing tree or cut products such as sawn logs, as well as the determination or prediction of the growth rate. The volume equation is defined as various mathematical statements applied to the determination of quantities (Shuaibu, 2014). It is imperative to increase the supply of lumber, poles and picketing materials for socio-economic development through adequate forest stand measurements to determine and improve the quantity and quality of these stands. Adegoke et al. (2010) stated that the socioeconomic development of any country depends largely on the efficient use of its natural resources. The importance of direct measurements of standing trees can not be overstated to obtain basic data on the relationship between different tree dimensions and volume used to estimate the volumes of other standing trees. Clutter et al. (1983) and Husch et al. (2003) explained that the stem volume of a tree is considered a function of the independent variables (diameter, height) and shape expressed as follows: $V=f(D$, $\mathrm{H}, \mathrm{F}$ ) where $\mathrm{V}=$ volume, $\mathrm{D}=$ diameter in $\mathrm{cm}, \mathrm{H}=$ total height, market value or height up to a specific limit and $\mathrm{F}=$ shape measurement such as Girrard shape class or absolute shape quotient.

Diameter and height measurements are essential variables in determining volume. According to Shuaibu and Alao (2013), the diameter of a tree is a random variable that depends on age and height. Therefore, the size distribution of tree diameter in stands describes forest structure and can be used to estimate stand volume and biomass, forest biodiversity and density management. Although volume equations have been studied for many years, they continue to attract forest research. Indeed, there is no single theory of volume that can be used satisfactorily for all species; no single volume model is best for all purposes and volume equations must be more accurate, flexible, valid and normal in their predictions. Forestry measures also need to be improved as market requirements for timber, poles and firewood have become more specific in recent years and current stock volumes and future growth potential are important information for sustainable forest management (Shuaibu and Alao, 2016).

The objective of this study is to evaluate tree volume equations for Scots pine tree species (Pinus sylvestrix var mongolica) in the boreal forests of northeastern China and set up a comparison of the inequalities between the volume-diameter relationships between the eight ecoregions; see if these volume equations are statistically justified to 
verify ecoregion differences for selected Scots pine species and to assess the associated bias when a regional model is compared to individual ecoregion models.

\section{Materials and Methods}

\section{Study area and data}

The study was conducted in the cold temperate forest regions of the Eastern Daxing'an Mountains who are the largest area of boreal forests in China (Hu et al., 2017) and is taking particularly the Northern slope of Yilehuli Mountains in Heilongjiang Province, northeast China (from $121^{\circ} 12^{\prime} \mathrm{E}$ to $127^{\circ} 00^{\prime} \mathrm{E}$ and from $50^{\circ} 10^{\prime} \mathrm{N}$ to $53^{\circ} 33^{\prime} \mathrm{N}$ ) (Figure 1). The elevation of the area ranges from 300 to $1520 \mathrm{~m}$ above the sea level. The mean annual rainfall ranges from 500 to $750 \mathrm{~mm}$ and mean annual temperature is from -1 to $-2.8^{\circ} \mathrm{C}$ (Enzinga and Jiang, 2019).

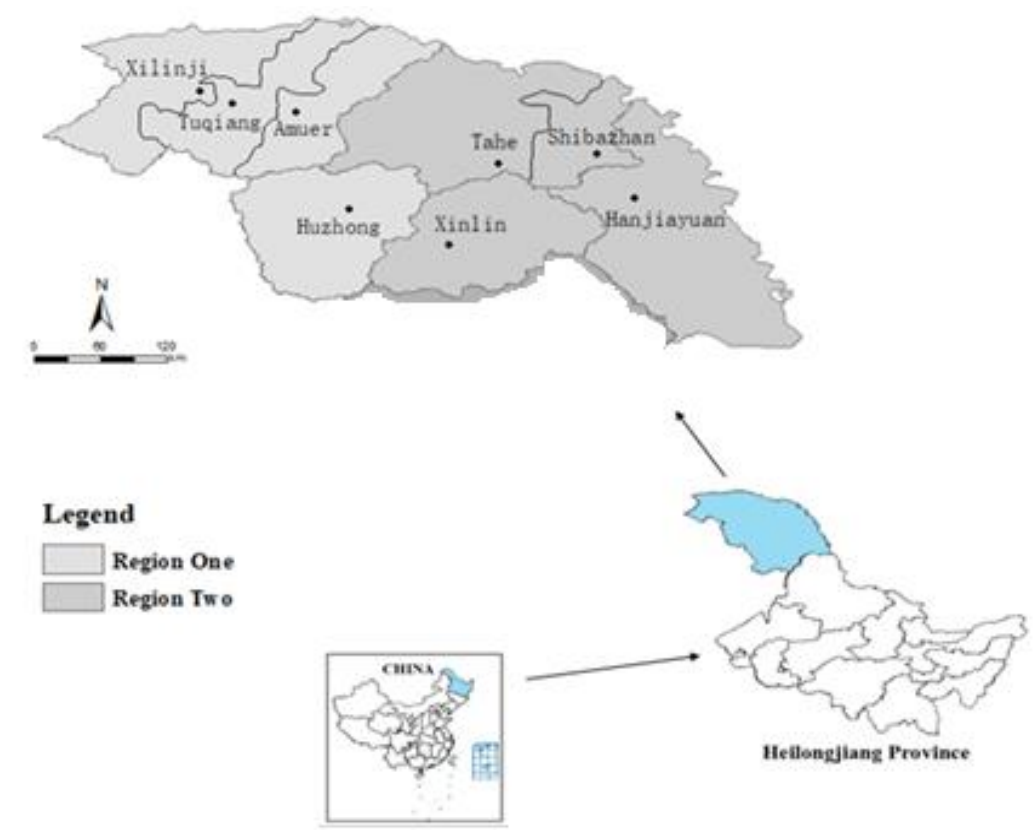

Figure 1. The geographical location of study area in the Northeast China

The two major regions (Zhang et al., 1992) employed are depicted in Figure 1 and include:

- Region 1: The northwest of the northern slope of Yilehuli Mountains (NWYLHLM) which includes four subregions: Xilinji (XLJ), Tuqiang (TQ), Amuer (AME), Huzhong (HZ).

- Region 2: The southeast of the northern slope of Yilehuli Mountains (SAYLHLM) which includes four subregions: Xinlin (XL), Tahe (TH), Shibazhan (SBZ), Hanjiayuan (HJY).

A total of 1294 destructively sampled Pinus sylvestrix var. mongolica trees species were used in this investigation. These trees were felled throughout the forest inventory areas of northeast China and all sampled trees were selected to ensure a representative distribution across a range of height and diameter classes within stands varying in 
density, height, site condition, age and stand structure. Diameters at breast height (DBH, defined as $1.3 \mathrm{~m}$ above the ground) outside bark were measured for all sampled trees. Trees were felled to measure total height and their diameter outside bark near ground and at $2,4,6,8,10,15,20,30,40,50,60,70,80$ and $90 \%$ of total height. Measurements for two perpendicular diameters (over bark) were taken in each part and arithmetically averaged. Smalian's formula (Eq.l) was used to calculate the log volumes in cubic meters. Total stem volume (over bark) above stump was computed by adding the logs volumes (over bark) and volume of the top section. Trees possessing broken tops, obvious cankers or crooked boles were excluded from the analysis. Summary statistics for tree diameter and total volume are provided for each subregion, the NWYLHLM, and SAYLHLM regions and all data combined (Overall) in Table 1.

Table 1. Summary statistics of tree diameter (DBH) at breast height, total height $(H)$, total volume $(V)$ for regional and ecoregional data sets for Scots pine

\begin{tabular}{c|ccccc|cccc|cccc}
\hline \multicolumn{9}{c}{ DBH $(\mathbf{c m})$} & \multicolumn{4}{c|}{ H $(\mathbf{m})$} & \multicolumn{4}{c}{ V $\left(\mathbf{m}^{\mathbf{3}}\right)$} \\
\hline Ecoregion & N & Mean & STD & Min & Max & Mean & STD & Min & Max & Mean & STD & Min & Max \\
\hline XL & $\mathbf{6 5}$ & 35.79 & 9.70 & 8.60 & 64.00 & 18.52 & 2.35 & 10.80 & 23.30 & 0.94 & 0.55 & 0.03 & 3.78 \\
TH & $\mathbf{1 2 0}$ & 19.63 & 11.20 & 5.00 & 49.00 & 13.91 & 5.23 & 5.90 & 26.50 & 0.32 & 0.40 & 0.01 & 2.03 \\
HZ & $\mathbf{1 3 5}$ & 30.09 & 12.68 & 5.40 & 57.60 & 17.50 & 3.33 & 5.00 & 23.90 & 0.76 & 0.56 & 0.01 & 2.28 \\
SBZ & $\mathbf{6 8}$ & 19.90 & 10.69 & 5.40 & 41.30 & 14.31 & 4.05 & 7.10 & 24.20 & 0.31 & 0.35 & 0.01 & 1.66 \\
HJY & $\mathbf{3 3 5}$ & 25.05 & 10.86 & 5.20 & 54.00 & 18.41 & 4.46 & 6.10 & 25.60 & 0.56 & 0.48 & 0.01 & 2.61 \\
XLJ & $\mathbf{1 8 9}$ & 18.81 & 10.94 & 5.00 & 52.30 & 15.46 & 4.31 & 7.10 & 23.90 & 0.31 & 0.36 & 0.01 & 1.74 \\
TQ & $\mathbf{1 8 4}$ & 28.22 & 12.11 & 6.30 & 50.70 & 18.45 & 4.31 & 5.80 & 25.70 & 0.72 & 0.60 & 0.01 & 2.38 \\
AME & $\mathbf{1 9 8}$ & 36.16 & 11.88 & 5.30 & 55.90 & 19.68 & 3.77 & 7.04 & 25.40 & 1.09 & 0.63 & 0.01 & 2.55 \\
NWYLHLM & $\mathbf{7 0 6}$ & $\mathbf{2 8 . 2 9}$ & $\mathbf{1 3 . 4 9}$ & $\mathbf{5 . 0 0}$ & $\mathbf{5 7 . 6 0}$ & $\mathbf{1 7 . 8 1}$ & $\mathbf{4 . 2 9}$ & $\mathbf{5 . 0 0}$ & $\mathbf{2 5 . 7 0}$ & $\mathbf{0 . 7 2}$ & $\mathbf{0 . 6 2}$ & $\mathbf{0 . 0 1}$ & $\mathbf{2 . 5 5}$ \\
SAYLHLM & $\mathbf{5 8 8}$ & $\mathbf{2 4 . 5 3}$ & $\mathbf{1 1 . 7 2}$ & $\mathbf{5 . 0 0}$ & $\mathbf{6 4 . 0 0}$ & $\mathbf{1 7 . 0 3}$ & $\mathbf{4 . 8 5}$ & $\mathbf{5 . 9 0}$ & $\mathbf{2 6 . 5 0}$ & $\mathbf{0 . 5 2}$ & $\mathbf{0 . 4 9}$ & $\mathbf{0 . 0 1}$ & $\mathbf{3 . 7 8}$ \\
Overall & $\mathbf{1 2 9 4}$ & $\mathbf{2 6 . 5 8}$ & $\mathbf{1 2 . 8 5}$ & $\mathbf{5 . 0 0}$ & $\mathbf{6 4 . 0 0}$ & $\mathbf{1 7 . 4 6}$ & $\mathbf{4 . 5 7}$ & $\mathbf{5 . 0 0}$ & $\mathbf{2 6 . 5 0}$ & $\mathbf{0 . 6 3}$ & $\mathbf{0 . 5 8}$ & $\mathbf{0 . 0 1}$ & $\mathbf{3 . 7 8}$ \\
\hline
\end{tabular}

Note: N-sample size (number of trees), STD-standard deviation, Min.-minimum, Max.-maximum

\section{Data and Methods}

Smalian's Formula

$$
V=\frac{S_{1}+S_{2}}{2} \times l
$$

where:

$\mathrm{V}=$ is the Volume of logs in $\mathrm{m}^{3}$,

$S_{1}=$ is the area at the small end of the $\log$ in $m^{2}$,

$S_{2}=$ is the area at the large end of the $\log$ in $\mathrm{m}^{2}$,

$l=$ is the length of the $\log$ in $m$.

\section{Base volume model selection}

A total of eighteen volume equations (Table 2) were selected from the literature (Alegria and Tome, 2011; Özçelik, 2019). In these studies, several models of volume equations are used in different forms to develop tree volume equations (Saraçoğlu, 1988; Bi and Hamilton, 1998; Bailey, 1994; Yavuz, 1999; Misır and Misır, 2004; Teshome, 2005; Akindele and LeMay, 2006; Perez, 2008; Alegria and Tome, 2011; Hjelm and Johansson, 2012; Stolarikova et al., 2014; Malata et al., 2017; Lee et al., 2017; Özçelik 
and Çevlik, 2017; Kitikidou et al., 2017; Sakıcı et al., 2018). These equations were examined and evaluated to select the best model for further analysis.

Table 2. Volume functions selected for evaluation

\begin{tabular}{|c|c|c|}
\hline Function form & References & Number \\
\hline $\mathrm{V}=\mathrm{a}+\left(\mathrm{bD}^{2} h\right)$ & Borset (1954) & (1) \\
\hline$V=a D^{b} H^{c}$ & Bailey (1994) & (2) \\
\hline$V=(a+b D)^{2}$ & Perez and Kanninen (2003) & (3) \\
\hline $\mathrm{V}=\mathrm{aD}^{2} \mathrm{H}$ & Spurr (1952) & (4) \\
\hline$V=\frac{D^{2}}{b /}$ & Honer (1967) & (5) \\
\hline $\mathrm{V}=\mathrm{a}+\mathrm{bD}^{2} \mathrm{H}+\mathrm{cH}$ & Rachid-Casnati et al. (2014) & (6) \\
\hline & Takata (1958) & (7) \\
\hline$V=a+b D^{c} H^{d}$ & Burkhart (1977) & (8) \\
\hline$V=a+b(H / D)^{c} D^{2} H$ & Teshome (2005) & (9) \\
\hline $\mathrm{V}=\mathrm{D}^{2}(\mathrm{a}+\mathrm{bH})$ & Ogaya (1968) & (10) \\
\hline $\mathrm{V}=\mathrm{aD} \mathrm{D}^{2}+\mathrm{bD^{2 }} \mathrm{H}-\mathrm{cD}^{2} \mathrm{H}^{2}-\mathrm{dH}+\mathrm{eDH} \mathrm{H}^{2}$ & Eriksson (1973) & (11) \\
\hline $\mathrm{V}=\mathrm{a}+\mathrm{b} \mathrm{D}^{2} \mathrm{H}+\mathrm{cD^{3 }} \mathrm{H}+\mathrm{dD}^{2} \mathrm{H}^{2}+\mathrm{eH}$ & Bi and Hamilton (1998) & (12) \\
\hline $\mathrm{V}=\mathrm{a}\left(\mathrm{D}^{2} \mathrm{H}\right)^{\mathrm{b}}$ & Malata et al. (2017) & (13) \\
\hline $\mathrm{V}=\mathrm{a}\left(\mathrm{D}^{2}\right)^{\mathrm{b}} \mathrm{H}^{\mathrm{c}}$ & Malata et al. (2017) & (14) \\
\hline $\mathrm{V}=\mathrm{a}+\mathrm{b} \mathrm{D}^{2}+\mathrm{cD}^{2} \mathrm{H}^{2}$ & Alegria and Tome (2011) & (15) \\
\hline 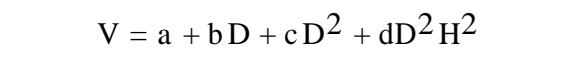 & Alegria and Tome (2011) & (16) \\
\hline $\mathrm{V}=\mathrm{a}+\mathrm{bDH}+\mathrm{cDH}^{2}+\mathrm{dD}^{2} \mathrm{H}^{2}$ & Alegria and Tome (2011) & (17) \\
\hline $\mathrm{V}=\mathrm{a}+\mathrm{bD}+\mathrm{cDH} \mathrm{H}^{2}+\mathrm{dD}^{2} \mathrm{H}^{2}$ & Alegria and Tome (2011) & (18) \\
\hline
\end{tabular}

Note: $\mathrm{V}=$ total Volume $\left(\mathrm{m}^{3}\right)$; $\mathrm{D}=$ diameter at breast height outside bark $(\mathrm{cm}) ; \mathrm{H}=$ total height $(\mathrm{m}) ; \mathrm{a}, \mathrm{b}, \mathrm{c}$, $\mathrm{d}, \mathrm{e}=$ parameters to be estimated

Through comparisons, the Schumacher and Hall (Bailey, 1994) function (model 2) was found to provide consistent and accurate results, and was therefore considered one of the best non-linear functions to describe the total volume of the Scots pine and selected as the base model:

$$
V=a D^{b} H^{c}
$$

where $\mathrm{V}$ is volume in cubic meter $\left(\mathrm{m}^{3}\right), \mathrm{D}$ is the tree diameter at breast height (DBH) $(\mathrm{cm}), \mathrm{H}$ is the total height $(\mathrm{m}),(\mathrm{a}, \mathrm{b}$, and $\mathrm{c})$ are the parameters.

Equation 2 was fit to: (1) the overall data, (2) the NWYLHLM region data (region 1), (3) the SAYLHLM region data (region 2) and (4) each of the eight ecoregions separately. The PROC NLIN procedure in the Statistical Analysis System (SAS Institute, Inc. 2002) was utilized to estimate the model parameters and model statistics.

To assess whether the total volume equations are different among regions and ecoregions, the non-linear extra sum of squares method was used (Bates and Watts, 1988; Neter et al., 1996). This method demands the fitting of full and reduced models and has commonly been applied to evaluate if separate models are necessary for different species or different ecoregions and geographic regions (Huang et al., 2000; Peng et al., 2001; Zhang et al., 2002; Castedo-Dorado et al., 2005; Corral-Rivas et al., 
2007). The full model corresponds to different sets of parameters for each subregions and is gotten by enlarging each parameter by including an associated parameter and a dummy variable to distinguish among ecoregions. The reduced model corresponds to the same set of global parameters for all ecoregions. Using Indicator (dummy) variable approach for the Equation 2, the full model of the volume function can be written as:

$$
V=\left(a+\sum_{i=1}^{k} a_{i} r_{i}\right) D^{\left(b+\sum_{i=1}^{k} b_{i} r_{i}\right)} H^{\left(c+\sum_{i=1}^{k} c_{i} r_{i}\right)}
$$

where:

$\mathrm{V}=$ volume parameter tested,

$\mathrm{r}_{\mathrm{i}}=$ indicator variable for regions and ecoregions,

$\mathrm{D}=$ tree dbh (in $\mathrm{cm})$,

$\mathrm{a}, \mathrm{b}, \mathrm{c}=$ parameters to be estimated from the data,

$\mathrm{k}=$ the number of indicator variables.

\section{Evaluate the overall volume differences among ecoregions}

This procedure involves the use of seven indicator variables $(\mathrm{k}=7)$ which are needed in Equation 3 for eight ecoregions in the full model form in this case. They are defined as follows:

If subregion $=\mathrm{XL}, \mathrm{z}_{1}=1$, all other $\mathrm{zi}=0$.

If subregion $=\mathrm{TH}, \mathrm{z}_{2}=1$, all other $\mathrm{zi}=0$.

If subregion $=\mathrm{HZ}, \mathrm{z}_{3}=1$, all other $\mathrm{zi}=0$.

If subregion $=\mathrm{SBZ}, \mathrm{z}_{4}=1$, all other $\mathrm{zi}=0$.

If subregion $=\mathrm{HJY}, \mathrm{z}_{5}=1$, all other $\mathrm{zi}=0$.

If subregion $=\mathrm{XLJ}, \mathrm{z}_{6}=1$, all other $\mathrm{zi}=0$.

If subregion $=\mathrm{TQ}, \mathrm{z}_{7}=1$, all other $\mathrm{zi}=0$.

If subregion $=\mathrm{AME}$, all other $\mathrm{zi}=0$.

While the reduced model form is represented by a three parameters model (Equation 2) representing the volume relationship across all ecoregions.

\section{Evaluate the volume differences between the two regions}

To test the difference between region NWYLHLM and SAYLHLM, one indicator variable $(\mathrm{k}=1)$ can be defined: if region $=$ NWYLHLM, $\mathrm{z}_{1}=1$; and if region $=$ SAYLHLM, $\mathrm{z}_{1}=0$. Similarly, the full model (Equation 3 ) has 6 estimable parameters.

\section{Evaluate the volume differences between the eight ecoregions}

A total of 28 ecoregion pairs can be formulated to test the pairwise differences between the eight ecoregions. The 28 testing pairs require 28 full models that take the form of Equation 3, and 28 reduced models that take the form of Equation 2. For example, to test the difference between ecoregion $\mathrm{TH}$ vs. HZ, one indicator variable $(\mathrm{k}=1)$ can be defined: if ecoregion $=\mathrm{TH}, \mathrm{z}_{1}=1$; and if ecoregion $=\mathrm{HZ}, \mathrm{z}_{1}=0$. Similarly, the full model (Equation 3) has 6 estimable parameters. All the reduced models for these tests take the form of Equation 2 with 3 parameters. 


\section{Evaluate statistic}

The significance of the full and reduced model comparisons were based on an F-test of the form:

$$
F=\frac{\frac{S S E_{R}-S S E_{F}}{d f_{R}-d f_{F}}}{\frac{S S E_{F}}{d f_{F}}}
$$

where $S S E_{R}$ is the error sum of squares of a reduced model with the degrees of freedom $d f_{R}$, and $S S E_{F}$ is the error sum of squares of a full model with the degrees of freedom $d f_{F}$. This test statistic is F-distributed for a non-linear model if the data used represent a large sample generally; the F-test is significant if the P-value for the test is less than 0.05 .

In order to understand the consequences of inappropriate application of a volume model in different ecoregions, each of the eleven models (global model, regional model 1 (NWYLHLM 1), regional model 2 (SAYLHLM 2), and 8 ecoregional models was used to predict total volume of trees for each ecoregion.

To quantify the magnitude of the prediction error when a specific region model is used, the average volume prediction error $(\bar{\varepsilon})$, the standard error of the prediction error $\left(\mathrm{S}_{\mathrm{e}}\right)$, and the prediction bias as a percentage of average "real" volume (\% bias) were calculated and defined as:

$$
\begin{gathered}
\bar{\varepsilon}=\frac{\sum_{i=1}^{m}\left(\hat{V}_{i}-V_{i}\right)}{m} \\
S_{e}=\sqrt{\frac{\sum_{i=1}^{m}(e-\bar{s})^{2}}{m-1}} \\
\operatorname{Bias}(\%)=\bar{\varepsilon} / \bar{V} \times 100
\end{gathered}
$$

where:

$\mathrm{m}=$ Number of trees,

$V_{i}=$ Data reported volume for tree $\mathrm{i}$,

$\widehat{V}_{i}=$ Predicted volume for tree i,

$\bar{V}=$ Mean data reported volume.

\section{Results and Discussion}

\section{Model fitting to regional and ecoregional data}

Based on the different data sets, Equation 2 was separately fitted using non-linear least squares. Parameter estimates and MSE for each ecoregion and region are displayed in Table 3. In all situations, parameter estimates and model forms were statistically significant $(\mathrm{P}<0.01)$. Among the eight ecoregional models, the lowest MSE value was found in the TH ecoregion, and the highest MSE value was found in the AME ecoregion. The parameter estimates varied among the eight ecoregions, indicating that each ecoregion may have a different volume with $\mathrm{DBH}$ and $\mathrm{H}$ relationship from others. The three regional models also have different parameter estimates. 
Table 3. Parameter estimates and MSE of volume function for the regional and ecoregional models

\begin{tabular}{c|c|c|c|c|c}
\hline Ecoregions & $\mathbf{N}$ & $\mathbf{a}$ & $\mathbf{b}$ & $\mathbf{c}$ & MSE \\
\hline XL & 65 & 0.000020 & 2.0737 & 1.0984 & 0.0121 \\
TH & 120 & 0.000029 & 1.8453 & 1.2382 & 0.00078 \\
HZ & 135 & 0.000200 & 1.9262 & 0.5259 & 0.00522 \\
SBZ & 68 & 0.000015 & 1.8184 & 1.5004 & 0.00233 \\
HJY & 335 & 0.000081 & 2.1093 & 0.6063 & 0.00657 \\
XLJ & 189 & 0.000132 & 1.8660 & 0.7028 & 0.0012 \\
TQ & 184 & 0.000044 & 1.5513 & 1.4665 & 0.0146 \\
AME & 198 & 0.000117 & 1.9022 & 0.7312 & 0.0159 \\
NWYLHLM & $\mathbf{7 0 6}$ & $\mathbf{0 . 0 0 0 1 1 1}$ & $\mathbf{1 . 9 0 4 1}$ & $\mathbf{0 . 7 4 5 3}$ & $\mathbf{0 . 0 1 0 9}$ \\
SAYLHLM & $\mathbf{5 8 8}$ & $\mathbf{0 . 0 0 0 0 3 4}$ & $\mathbf{2 . 0 6 8 6}$ & $\mathbf{0 . 9 3 1 3}$ & $\mathbf{0 . 0 0 6 3}$ \\
Overall & $\mathbf{1 2 9 4}$ & $\mathbf{0 . 0 0 0 0 7 5}$ & $\mathbf{1 . 9 7 1 9}$ & $\mathbf{0 . 7 9 0 6}$ & $\mathbf{0 . 0 0 9 1 5}$ \\
\hline
\end{tabular}

Note: N-sample size (number of tree), a, b, c-three parameters of volume model, MSE-model mean squared error

\section{Comparison of the total volume equations between regions and ecoregions}

Table 4 shows the testing results for the differences of the overall volume models for the eight ecoregions. The F-test indicates that there are differences among the total volume models from eight ecoregions $(\mathrm{P}<0.0001)$. This implies that the overall model is not sufficient to describe the volume with $\mathrm{DBH}$ and $\mathrm{H}$ relationships for the eight ecoregions selected. The difference between the different regions (NWYLHLMSAYLHLM) was also tested and the P-values were less than 0.0001 for the two regional paired comparisons. This means that the difference in volume between the two geographic regions is also statistically significant. The same approach was used to test for differences among the eight ecoregions (Table 4). Among the 28 pairs of ecoregion comparisons, only three ecoregion pairs (e.g., XL versus SBZ, HZ versus AME, and $\mathrm{SBZ}$ versus TQ) showed the non-significant difference $(\mathrm{P}>0.05)$.

\section{Prediction errors of applying overall and regional volume equations to each ecoregion}

According to the tests above, there were significant differences for many paired comparisons of the volume model among the eight ecoregions and between regions. Inappropriately applying a total volume model in these ecoregions may result in prediction biases. To understand the consequences, all eleven models (overall model, NWYLHLM model, SAYLHLM model and eight sub-regional models) were used to predict total tree volume for each ecoregion individually.

If the overall model was used to predict the volume of trees in each ecoregion, excessive or underestimated predictions were made for different ecoregions. On average, the overall model under-estimated (i.e., positive Bias \%) tree volume from $0.1 \%$ to $3.2 \%$ for ecoregions AME, HJY, TQ, and HZ, and over-estimated (i.e., negative Bias \%) tree volume about $-2.1 \%$ to $-8.1 \%$ in ecoregions XL, XLJ, SBZ and TH (Table 5).

Applying the NWYLHLM regional model to each ecoregion would result in similar patterns and magnitudes of the prediction errors as the overall model. This model underestimated tree volumes in the HZ (1.9\%), AME (0.07\%), and over-estimated tree volumes in the XL (-3.01\%), TH (-11.1\%), SBZ (-9.8\%), HJY (-1.4\%), XLJ (-9.3\%) and TQ $(-0.0735 \%)$ (Table 6). 
Mbangilwa et al.: Evaluation of ecoregion-based volume equations for Scots pine (Pinus sylvestrix) in the Eastern Daxing'an Mountains, Northeast China

$$
\text { - } 4949 \text { - }
$$

Table 4. F-test for testing the difference between regions and among eight ecoregions

\begin{tabular}{|c|c|c|c|c|c|c|c|c|c|c|}
\hline \multirow{2}{*}{ Subregions } & \multirow{2}{*}{$\mathbf{n}$} & \multicolumn{3}{|c|}{ Full Model } & \multicolumn{3}{|c|}{ Reduced Model } & \multicolumn{3}{|c|}{ Extra sum of squares } \\
\hline & & $S S E_{F}$ & PF & $d f_{F}$ & $S S E_{R}$ & PR & $d f_{R}$ & $d f_{R}-d f_{F}$ & F-value & P-value \\
\hline Overall & 1294 & 9.8339 & 30 & 1267 & 11.8065 & 3 & 1291 & 24 & 10.5898 & 0.0000 \\
\hline $\begin{array}{l}\text { NWYLHLM- } \\
\text { SAYLHLM }\end{array}$ & 1294 & 11.3292 & 6 & 1288 & 11.8065 & 33 & 1291 & 3 & 18.0893 & 0.0000 \\
\hline $\mathrm{XL}-\mathrm{TH}$ & 185 & 0.8429 & 6 & 179 & 0.9774 & 3 & 182 & 3 & 9.5188 & 0.0000 \\
\hline $\mathrm{XL}-\mathrm{HZ}$ & 200 & 1.4410 & 6 & 194 & 1.7510 & 3 & 197 & 3 & 13.9109 & 0.0000 \\
\hline XL - SBZ & 133 & 0.9032 & 6 & 127 & 0.9322 & 3 & 130 & 3 & 1.3577 & 0.2587 \\
\hline XL - HJY & 400 & 2.9341 & 6 & 394 & 3.1322 & 3 & 397 & 3 & 8.8686 & 0.0000 \\
\hline XL - XLJ & 254 & 0.9753 & 6 & 248 & 1.2592 & 3 & 251 & 3 & 24.0628 & 0.0000 \\
\hline XL - TQ & 249 & 3.4031 & 6 & 243 & 3.9713 & 3 & 246 & 3 & 13.5243 & 0.0000 \\
\hline XL - AME & 263 & 3.8440 & 6 & 257 & 4.0791 & 3 & 260 & 3 & 5.2411 & 0.0015 \\
\hline $\mathrm{TH}-\mathrm{HZ}$ & 255 & 0.7807 & 6 & 249 & 1.2053 & 3 & 252 & 3 & 45.1421 & 0.0000 \\
\hline TH - SBZ & 188 & 0.2428 & 6 & 182 & 0.2786 & 3 & 185 & 3 & 8.9416 & 0.0000 \\
\hline TH - HJY & 455 & 2.2737 & 6 & 449 & 2.6379 & 3 & 452 & 3 & 23.9775 & 0.0000 \\
\hline TH - XLJ & 309 & 0.3150 & 6 & 303 & 0.3822 & 3 & 306 & 3 & 21.5336 & 0.0000 \\
\hline TH - TQ & 304 & 2.7428 & 6 & 298 & 2.8935 & 3 & 301 & 3 & 5.4611 & 0.0011 \\
\hline TH - AME & 318 & 3.1836 & 6 & 312 & 3.4648 & 3 & 315 & 3 & 9.1839 & 0.0000 \\
\hline $\mathrm{HZ}-\mathrm{SBZ}$ & 203 & 0.8409 & 6 & 197 & 1.1099 & 3 & 200 & 3 & 21.0047 & 0.0000 \\
\hline HZ - HJY & 470 & 2.8718 & 6 & 464 & 3.0242 & 3 & 467 & 3 & 8.2085 & 0.0000 \\
\hline HZ - XLJ & 324 & 0.9131 & 6 & 318 & 1.1756 & 3 & 321 & 3 & 30.4673 & 0.0000 \\
\hline HZ - TQ & 319 & 3.3409 & 6 & 313 & 3.8997 & 3 & 316 & 3 & 17.4522 & 0.0000 \\
\hline HZ - AME & 333 & 3.7817 & 6 & 327 & 3.8206 & 3 & 330 & 3 & 1.1204 & 0.3408 \\
\hline SBZ - HJY & 403 & 2.3340 & 6 & 397 & 2.5168 & 3 & 400 & 3 & 10.3639 & 0.0000 \\
\hline SBZ - XLJ & 257 & 0.3753 & 6 & 251 & 0.4846 & 3 & 254 & 3 & 24.3789 & 0.0000 \\
\hline SBZ - TQ & 252 & 2.8030 & 6 & 246 & 2.8453 & 3 & 249 & 3 & 1.2369 & 0.2968 \\
\hline SBZ - AME & 266 & 3.2439 & 6 & 260 & 3.4207 & 3 & 263 & 3 & 4.7232 & 0.0031 \\
\hline HJY - XLJ & 524 & 2.4062 & 6 & 518 & 2.8629 & 3 & 521 & 3 & 32.7782 & 0.0000 \\
\hline HJY - TQ & 519 & 4.8339 & 6 & 513 & 5.6557 & 3 & 516 & 3 & 29.0706 & 0.0000 \\
\hline HJY - AME & 533 & 5.2748 & 6 & 527 & 5.5064 & 3 & 530 & 3 & 7.7127 & 0.0000 \\
\hline XLJ - TQ & 373 & 2.8752 & 6 & 367 & 3.2028 & 3 & 370 & 3 & 13.9407 & 0.0000 \\
\hline XLJ - AME & 387 & 3.3161 & 6 & 381 & 3.6265 & 3 & 384 & 3 & 11.8870 & 0.0000 \\
\hline TQ - AME & 382 & 5.7438 & 6 & 376 & 6.1290 & 3 & 379 & 3 & 8.4049 & 0.0000 \\
\hline
\end{tabular}

Note: $\mathrm{N}$ - sample size, $\mathrm{SSE}_{\mathrm{F}}$ - error sum of squares of the full model, $\mathrm{df}_{\mathrm{F}}-$ degrees of freedom of $\mathrm{SSE}_{\mathrm{F}}$, $\mathrm{SSE}_{\mathrm{R}}-$ error sum of squares of reduced model, $\mathrm{df}_{\mathrm{R}}-$ degrees of freedom of $\mathrm{SSE}_{R}, \mathrm{P}$ is the number of parameters

Table 5. Prediction error of applying the overall model for each ecoregion

\begin{tabular}{c|c|c|c|c|c|c|c}
\hline Subregions & $\mathrm{N}$ & $\bar{V}(\mathrm{~m})$ & $\widehat{V}(\mathrm{~m})$ & $\bar{\varepsilon}$ & $S_{e}$ & $\mathrm{t}$ & $\operatorname{Bias}(\%)$ \\
\hline XL & 65 & 0.9352 & 0.9547 & -0.0195 & 0.1183 & -1.3284 & -2.0835 \\
TH & 120 & 0.3198 & 0.3456 & -0.0258 & 0.0479 & -5.9040 & -8.0736 \\
HZ & 135 & 0.7603 & 0.7360 & 0.0243 & 0.0768 & 3.6748 & 3.1946 \\
SBZ & 68 & 0.3136 & 0.3329 & -0.0194 & 0.0629 & -2.5392 & -6.1728 \\
HJY & 335 & 0.5550 & 0.5516 & 0.0034 & 0.0852 & 0.7356 & 0.6167 \\
XLJ & 189 & 0.3128 & 0.3319 & -0.0191 & 0.0507 & -5.1842 & -6.1184 \\
TQ & 184 & 0.7181 & 0.7117 & 0.0064 & 0.1329 & 0.6504 & 0.8876 \\
AME & 198 & 1.0919 & 1.0904 & 0.0015 & 0.1269 & 0.1655 & 0.1367 \\
\hline
\end{tabular}

Note: $\mathrm{N}$ - sample size, $\overline{\mathrm{V}}$ - average of observed tree volume, $\widehat{\mathrm{V}}$ - average of predicted tree volume from the model, $\mathrm{S}_{\mathrm{e}}-$ standard deviation of prediction error 
Table 6. Prediction errors of applying regional models to each ecoregion

\begin{tabular}{c|c|c|c|c|c|c|c}
\hline Reg-Eco & $\mathbf{N}$ & $\overline{\boldsymbol{V}}(\mathbf{m})$ & $\widehat{\boldsymbol{V}}(\mathbf{m})$ & $\overline{\boldsymbol{\varepsilon}}$ & $\boldsymbol{S}_{\boldsymbol{e}}$ & $\mathbf{t}$ & Bias $(\boldsymbol{\%})$ \\
\hline NWYLHLM - XL & 65 & 0.9352 & 0.9633 & -0.0281 & 0.1255 & -1.8056 & -3.0053 \\
NWYLHLM - TH & 120 & 0.3198 & 0.3554 & -0.0356 & 0.0502 & -7.7685 & -11.1237 \\
NWYLHLM - HZ & 135 & 0.7603 & 0.7455 & 0.0148 & 0.0756 & 2.2782 & 1.9507 \\
NWYLHLM - SBZ & 68 & 0.3136 & 0.3443 & -0.0307 & 0.0659 & -3.8394 & -9.7935 \\
NWYLHLM - HJY & 335 & 0.5550 & 0.5626 & -0.0076 & 0.0879 & -1.5896 & -1.3757 \\
NWYLHLM - XLJ & 189 & 0.3128 & 0.3419 & -0.0291 & 0.0493 & -8.1208 & -9.3051 \\
NWYLHLM - TQ & 184 & 0.7181 & 0.7186 & -0.0005 & 0.1312 & -0.0546 & -0.0735 \\
NWYLHLM - AME & 198 & 1.0919 & 1.0911 & 0.0008 & 0.1253 & 0.0886 & 0.0722 \\
\hline SAYLHLM - XL & 65 & 0.9352 & 0.9362 & -0.0009 & 0.1099 & -0.0702 & -0.1024 \\
SAYLHLM - TH & 120 & 0.3198 & 0.3301 & -0.0103 & 0.0448 & -2.5288 & -3.2368 \\
SAYLHLM - HZ & 135 & 0.7603 & 0.7177 & 0.0426 & 0.0837 & 5.9206 & 5.6079 \\
SAYLHLM - SBZ & 68 & 0.3136 & 0.3139 & -0.0003 & 0.0566 & -0.0498 & -0.1091 \\
SAYLHLM - HJY & 335 & 0.5550 & 0.5359 & 0.0190 & 0.0837 & 4.1592 & 3.4277 \\
SAYLHLM - XLJ & 189 & 0.3128 & 0.3168 & -0.0040 & 0.0548 & -1.0091 & -1.2857 \\
SAYLHLM - TQ & 184 & 0.7181 & 0.7037 & 0.0144 & 0.1389 & 1.4091 & 2.009 \\
SAYLHLM - AME & 198 & 1.0919 & 1.0908 & 0.0011 & 0.1367 & 0.1135 & 0.1009 \\
\hline
\end{tabular}

Note: $\mathrm{N}$ - sample size, $\overline{\mathrm{V}}$ - average of observed tree volume, $\widehat{\mathrm{V}}$ - average of predicted tree volume from the model, $\mathrm{S}_{\mathrm{e}}-$ standard deviation of prediction error

The same approach was used for SAYLHLM regional model to each ecoregion (Table 6). SAYLHLM regional model under-estimated tree volumes in the HZ (5.6\%), HJY (3.4\%), TQ (2.01\%), AME $(0.1 \%)$ and over-estimated tree volumes in the XL $(-0.1 \%)$, TH (-3.2\%), SBZ (-0.1\%) and XLJ (-1.3\%).

\section{Prediction errors of applying ecoregional equation to each ecoregion}

When the eight ecoregional models were applied to each ecoregion, they generally performed well in the ecoregions in which the models were developed. Otherwise, the models produced the prediction errors. The prediction biases ranged from $-1.2 \%$ to $7.5 \%$ in XL, from $-0.8 \%$ to $11.7 \%$ in $\mathrm{TH}$, from $-13.9 \%$ to $0.08 \%$ in $\mathrm{HZ}$, from $-3.5 \%$ to $10.3 \%$ in SBZ, from $-8.9 \%$ to $0.9 \%$ in HJY, from $-2.5 \%$ to $10.4 \%$ in XLJ, from $-11.6 \%$ to $9.4 \%$ in TQ and from $-11.7 \%$ to $1.5 \%$ in AME (Table 7). Figure 2 shows the mean prediction errors across 5-cm diameter classes when ecoregional models are applied to predict tree volume in each of the eight ecoregions separately. This further confirmed that ecoregional model developed in that ecoregion performed well for most diameter classes.

The expected results show that the different ecoregions have large differences in climatic, soil and ecological conditions. Corral-Rivas et al. (2007) and Brooks and Wiant (2008) reported in their study of the use of stump diameter to estimate DBH and tree volumes (V) at El Salto, Durango, Mexico and Ecoregion-based local volume equations for Appalachian hardwoods, USA. Part of the differences between the dbh and volume models between tree species may be caused by differences in genetics, growing conditions, and site quality. Previous studies of different species have also revealed differences between ecoregion-based height-diameter models (Huang, 1999; Huang et al., 1999; Zhang et al., 2002; Peng et al., 2004; Brooks and Wiant, 2005; Özçelik et al., 2014, 2016; Chourou, 2014; Enzinga and Jiang, 2019). In our case, the updated ecoregion classification in the cold temperate coniferous forest regions of Eastern Daxing'an Mountains (Figure 1) provides comprehensive information on changes in the relationships between ecoregions and tree species of Pinus silvestrix along ecological and macroclimatic gradients from different regions. These ecoregions are characterized by large climatic regimes that include temperature and precipitation, soil moisture and nutrient regimes, and succession and vegetation types (Hills, 1959, 1960; CEC, 1997; ELC Working Group, 2000). 
-4951 -

Table 7. Prediction errors of applying a specific ecoregion model to each ecoregion

\begin{tabular}{|c|c|c|c|c|c|c|c|}
\hline Subregions & $\mathbf{N}$ & $\bar{V}(\mathbf{m})$ & $\widehat{V}(\mathbf{m})$ & $\bar{\varepsilon}$ & $S_{e}$ & $\mathbf{t}$ & $\operatorname{Bias}(\%)$ \\
\hline \multicolumn{8}{|l|}{ XL model } \\
\hline XL - XL & 65 & 0.9352 & 0.9193 & 0.0159 & 0.1079 & 1.1904 & 1.7047 \\
\hline XL - TH & 120 & 0.3198 & 0.3235 & -0.0037 & 0.0435 & -0.9268 & -1.1510 \\
\hline XL - HZ & 135 & 0.7603 & 0.7036 & 0.0567 & 0.0908 & 7.2498 & 7.4529 \\
\hline XL - SBZ & 68 & 0.3136 & 0.3044 & 0.0092 & 0.0518 & 1.4662 & 2.9399 \\
\hline XL - HJY & 335 & 0.5550 & 0.5326 & 0.0224 & 0.0865 & 4.7333 & 4.0319 \\
\hline XL - XLJ & 189 & 0.3128 & 0.3114 & 0.0014 & 0.0568 & 0.3298 & 0.4359 \\
\hline XL - TQ & 184 & 0.7181 & 0.7038 & 0.0142 & 0.1429 & 1.3528 & 1.9851 \\
\hline XL - AME & 198 & 1.0919 & 1.0904 & 0.0015 & 0.1454 & 0.1451 & 0.1373 \\
\hline \multicolumn{8}{|l|}{ TH model } \\
\hline TH - XL & 65 & 0.9352 & 0.8686 & 0.0666 & 0.1334 & 4.0237 & 7.1185 \\
\hline $\mathrm{TH}-\mathrm{TH}$ & 120 & 0.3198 & 0.3224 & -0.0026 & 0.0288 & -0.9789 & -0.8052 \\
\hline TH - HZ & 135 & 0.7603 & 0.6713 & 0.0889 & 0.1109 & 9.3206 & 11.7032 \\
\hline TH - SBZ & 68 & 0.3136 & 0.3044 & 0.0092 & 0.0510 & 1.4795 & 2.9203 \\
\hline TH - HJY & 335 & 0.5550 & 0.5331 & 0.0219 & 0.1026 & 3.9010 & 3.9401 \\
\hline TH - XLJ & 189 & 0.3128 & 0.3149 & -0.0021 & 0.0432 & -0.6728 & -0.6765 \\
\hline TH - TQ & 184 & 0.7181 & 0.6861 & 0.0319 & 0.1248 & 3.4741 & 4.4509 \\
\hline TH - AME & 198 & 1.0919 & 1.0322 & 0.0597 & 0.1345 & 6.2439 & 5.4667 \\
\hline \multicolumn{8}{|l|}{ HZ model } \\
\hline HZ - XL & 65 & 0.9352 & 0.9858 & -0.0506 & 0.1323 & -3.0819 & -5.4076 \\
\hline $\mathrm{HZ}$ - TH & 120 & 0.3198 & 0.3641 & -0.0443 & 0.0619 & -7.8473 & -13.8603 \\
\hline $\mathrm{HZ}-\mathrm{HZ}$ & 135 & 0.7603 & 0.7635 & -0.0032 & 0.0716 & -0.5242 & -0.4252 \\
\hline HZ - SBZ & 68 & 0.3136 & 0.3564 & -0.0428 & 0.0754 & -4.6792 & -13.6435 \\
\hline HZ - HJY & 335 & 0.5550 & 0.5639 & -0.0089 & 0.0878 & -1.8544 & -1.6029 \\
\hline HZ - XLJ & 189 & 0.3128 & 0.3472 & -0.0345 & 0.0486 & -9.7367 & -11.0184 \\
\hline HZ - TQ & 184 & 0.7181 & 0.7175 & 0.0005 & 0.1366 & 0.0545 & 0.0765 \\
\hline HZ - AME & 198 & 1.0918 & 1.0928 & -0.0009 & 0.1273 & -0.1049 & -0.0869 \\
\hline \multicolumn{8}{|l|}{ SBZ model } \\
\hline SBZ - XL & 65 & 0.9352 & 0.8832 & 0.05199 & 0.1277 & 3.2817 & 5.5595 \\
\hline SBZ - TH & 120 & 0.3198 & 0.3296 & -0.0098 & 0.0459 & -2.3302 & -3.0569 \\
\hline SBZ - HZ & 135 & 0.7603 & 0.6820 & 0.0783 & 0.1181 & 7.6986 & 10.2934 \\
\hline SBZ - SBZ & 68 & 0.3136 & 0.3064 & 0.0071 & 0.0471 & 1.2503 & 2.2755 \\
\hline SBZ - HJY & 335 & 0.5550 & 0.5563 & -0.0013 & 0.1063 & -0.2239 & -0.2343 \\
\hline SBZ - XLJ & 189 & 0.3128 & 0.3236 & -0.0108 & 0.0566 & -2.6365 & -3.4702 \\
\hline SBZ - TQ & 184 & 0.7181 & 0.7194 & -0.0013 & 0.1355 & -0.1343 & -0.1868 \\
\hline SBZ - AME & 198 & 1.0919 & 1.0770 & 0.0148 & 0.1489 & 1.4032 & 1.3601 \\
\hline \multicolumn{8}{|l|}{ HJY model } \\
\hline HJY - XL & 65 & 0.9352 & 0.9928 & -0.0576 & 0.1201 & -3.8677 & -6.1634 \\
\hline HJY - TH & 120 & 0.3198 & 0.3484 & -0.0286 & 0.0627 & -5.0008 & -8.9488 \\
\hline HJY - HZ & 135 & 0.7603 & 0.7617 & -0.0014 & 0.0833 & -0.1998 & -0.1886 \\
\hline HJY - SBZ & 68 & 0.3136 & 0.3368 & -0.0232 & 0.0711 & -2.6901 & -7.3933 \\
\hline HJY - HJY & 335 & 0.5550 & 0.5499 & 0.0051 & 0.0807 & 1.1471 & 0.9116 \\
\hline HJY - XLJ & 189 & 0.3128 & 0.3307 & -0.0179 & 0.0609 & -4.0378 & -5.7259 \\
\hline HJY - TQ & 184 & 0.7181 & 0.7179 & 0.0002 & 0.1433 & 0.0218 & 0.0321 \\
\hline HJY - AME & 198 & 1.0919 & 1.1206 & -0.0287 & 0.1360 & -2.9686 & -2.6277 \\
\hline \multicolumn{8}{|l|}{ XLJ model } \\
\hline XLJ - XL & 65 & 0.9352 & 0.8785 & 0.0567 & 0.1523 & 2.9991 & 6.0591 \\
\hline XLJ - TH & 120 & 0.3198 & 0.3278 & -0.0081 & 0.0514 & -1.7201 & -2.5235 \\
\hline XLJ - HZ & 135 & 0.7603 & 0.6815 & 0.0788 & 0.1006 & 9.0999 & 10.3661 \\
\hline XLJ - SBZ & 68 & 0.3136 & 0.3189 & -0.0053 & 0.0689 & -0.6373 & -1.6998 \\
\hline XLJ - HJY & 335 & 0.5550 & 0.5157 & 0.0393 & 0.1088 & 6.6097 & 7.0821 \\
\hline XLJ - XLJ & 189 & 0.3128 & 0.3155 & -0.0027 & 0.0344 & -1.1024 & -0.8816 \\
\hline XLJ - TQ & 184 & 0.7181 & 0.6546 & 0.0635 & 0.1431 & 6.0196 & 8.8414 \\
\hline XLJ - AME & 198 & 1.0919 & 0.9887 & 0.1032 & 0.1432 & 10.1385 & 9.4492 \\
\hline \multicolumn{8}{|l|}{ TQ model } \\
\hline TQ - XL & 65 & 0.9352 & 0.8789 & 0.0563 & 0.1721 & 2.6386 & 6.0235 \\
\hline TQ - TH & 120 & 0.3198 & 0.3498 & -0.0300 & 0.0449 & -7.3275 & -9.3986 \\
\hline TQ - HZ & 135 & 0.7603 & 0.6890 & 0.0713 & 0.1423 & 5.8229 & 9.3779 \\
\hline TQ - SBZ & 68 & 0.3136 & 0.3308 & -0.0172 & 0.0529 & -2.6879 & -5.4961 \\
\hline TQ - HJY & 335 & 0.5550 & 0.5847 & -0.0297 & 0.1261 & -4.3129 & -5.3526 \\
\hline TQ - XLJ & 189 & 0.3128 & 0.3491 & -0.0363 & 0.0542 & -9.2083 & -11.6156 \\
\hline TQ - TQ & 184 & 0.7181 & 0.7269 & -0.0088 & 0.1204 & -0.9941 & -1.2288 \\
\hline TQ - AME & 198 & 1.0919 & 1.0513 & 0.0405 & 0.1503 & 3.7956 & 3.7123 \\
\hline
\end{tabular}




\begin{tabular}{c|c|c|c|c|c|c|c}
\hline Subregions & $\mathbf{N}$ & $\overline{\boldsymbol{V}}(\mathbf{m})$ & $\widehat{\boldsymbol{V}}(\mathbf{m})$ & $\overline{\boldsymbol{\varepsilon}}$ & $\boldsymbol{S}_{\boldsymbol{e}}$ & $\mathbf{t}$ & Bias $(\%)$ \\
\hline AME model & & & & & & & \\
AME - XL & 65 & 0.9352 & 0.9672 & -0.0320 & 0.1258 & -2.0523 & -3.4251 \\
AME - TH & 120 & 0.3198 & 0.3571 & -0.0373 & 0.0513 & -7.9756 & -11.6782 \\
AME - HZ & 135 & 0.7603 & 0.7487 & 0.0116 & 0.0750 & 1.8000 & 1.5289 \\
AME - SBZ & 68 & 0.3136 & 0.3463 & -0.0327 & 0.0668 & -4.0393 & -10.4336 \\
AME - HJY & 335 & 0.5550 & 0.5646 & -0.0096 & 0.0877 & -1.9954 & -1.7236 \\
AME - XLJ & 189 & 0.3128 & 0.3434 & -0.0307 & 0.0498 & -8.4672 & -9.8101 \\
AME - TQ & 184 & 0.7181 & 0.7206 & -0.0025 & 0.1314 & -0.2590 & -0.3494 \\
AME - AME & 198 & 1.0919 & 1.0938 & -0.0019 & 0.1253 & -0.2191 & -0.1787 \\
\hline
\end{tabular}

Note: $\mathrm{N}$ - sample size, $\overline{\mathrm{V}}$ - average of observed tree volume, $\widehat{\mathrm{V}}$ - average of predicted tree volume from the model, $\mathrm{S}_{\mathrm{e}}-$ standard deviation of prediction error



Figure 2. Average prediction errors $(m)$ across 5-cm diameter classes when each ecoregional model is applied to predict total volume in each of the eight ecoregions with symbols: XL (star),

$T H$ (circle), HZ (triangle), SBZ (X), HJY (plus), XLJ (dot), TQ (diamond) and AME (Y) 
Enzinga and Jiang (2019) provide comprehensive analysis of the climatic characteristics of the eastern Daxing'an Mountains which include the two regions (NWYLHLM and SAYLHLM) selected for the study. In addition, local ecological conditions such as vegetation types also affect growth and productivity as well as species dominance in these ecoregions For example, in the 8 subregions selected for the study, it was demonstrated that the Scots pine (Pinus Sylvestrix var. mongolica) population was not present in the NDXAM region containing the subregions: Songling (SL), Jiagedaqi (JGDQ) within which the Scots pine stand was not observed by observing the previous 10 subregions of the Daxing'an mountains. Therefore, the combination of all climatic, environmental and vegetation factors plays an important role in determining the different volume relationships among the 8 ecoregions linked to our study.

These results are consistent with the last and recent results reported by Brooks and Wiant (2008), Li and Zeng (2016), and Liu and Jiang (2016). Based on six ecoregions from Central Appalachian, Unites States, Brooks and Wiant (2008) evaluated the ecoregion-based volume equations for six hardwood species and found that the average bias between a regional model with a single species and specific forms of ecoregion ranged from -9.1 to $8.5 \%$ for the gross volume of board feet, from -3.5 to $9.2 \%$ for the gross volume of marketable cubic feet, and -9.5 to $16.7 \%$ for the weight of the marketable dry bole. Li and Zeng (2016) used the datasets of Larix spp. from four regions (northeastern, northern, northwestern, and southwestern) of China and same total volume equation used in our study to test the difference among regions. Their results indicated that the difference of volume estimates was noticed between northeastern and northern regions, northern and northwestern regions. Based on the classification in eastern Daxing'an Mountains, Northeast China by Zhang et al. (1992), three regions were identified. Liu and Jiang (2016) evaluated the regional difference of volume estimates using dahurian larch (larix gmelinii) datasets from eastern Daxing'an Mountains. Results indicated that volume models were significant difference among different regions, therefore, region-based volume equation is required to avoid increasing prediction error. Enzinga and Jiang (2019) evaluated the region and subregion-based height-diameter models for dahurian larch (larix gmelinii) in Eastern Daxing'an Mountains which led to conclusions demonstrating that there were distinct variations in height-diameter relationships for Dahurian larch between the different subregions in three forest regions and that usually, height-diameter models based on ecoregions report forecasts more reliably on a regional basis and avoid likely errors that may arise when applying the models in other areas. The same is true in the case of our study on ecoregional assessments based on volume equation models in Northeast China.

\section{Conclusion}

In the study, the total tree volume equations were developed for Pinus sylvestrix var mongolica in northeastern China. Using dummy variables and the non-linear extra sum of squares procedure, the volume with diameter and total height relationship was not the same for all ecoregions when tested by regions and ecoregions of Scots pine. For comparisons by ecoregion, statistical differences in total volume were found in many ecoregions, which can be explained in part by the longitudinal, latitudinal and elevation properties that exist in the soil, the length of the season, growth rates and annual precipitation rates in these regions. This brings us to prove the importance of the 
relationship between the volume, the diameter and the total height of the trees of the Pinus sylvestrix var mongolica species studied.

Differences in height and diameter reported for the same northeast China ecoregions are probably the main factor behind the different volume models. The average bias varies at different percentage levels for the market value of wood in the two regions, the equations for total volume of trees specific to Scots pine and ecoregions are presented and can be easily used in situations of wood intrusion into the eight ecoregions, although there are significant volume relationships between the Pinus sylvestrix species in the two regions studied for this case. The inappropriate application of overall or regional volume models to these different ecoregions for Scots pine in Eastern Daxing'an Mountains can in this case lead to significant errors in the estimation of total volumes.

Apart from all these inverstigations we recommend the following:

- Develop different models for different ecoregions wherever the data are favorable;

- Furthermore, the difference in the growth of Pinus sylvestrix between the two regions as well as the eight ecoregions being explained in a summary manner, climatic research must be done in order to determine the factors responsible of the difference in tree growth between the two regions and the eight ecoregions on the one hand and on the other, to better understand the variations in the volumediameter and height relationship on large scales;

- In the light of the results obtained during this study, the predicted volumes of Pinus sylvestrix Var Mongolica trees, obtained through the development of models of volume equations in the two regions, can be used as explanatory variables for the calculation of the allowable cut by forestry managers. However, it is preferable to use the volume that has been predicted from ecoregional models since it enjoys, to our knowledge, unprecedented precision.

- Regarding the GIS aspect, the main objective of this article being to reflect the differences between regions and ecological regions from total volume models, in the future, we will recommend cartographic studies related to remote sensing at the level of different regions and ecoregions using GIS-based methods and finally to develop a quantitative and multivariate regionalization model capable of delineating ecoregions on several levels from remote sensed information and other spatial data on environmental and natural resources so have a general vision of the evolution of the forest cover and the landscape for each defined region and ecoregions. The development of the model will thus provide a new useful approach to the mapping of ecoregions for resource managers and researchers.

Acknowledgments. This research was financially supported by the National Key R \&D Program of China (grant No. 2017YFB0502700), National Natural Science Foundation of China (31570624), Applied Technology Research and Development Plan Project of Heilongjiang Province (GA19C006), and Fundamental Research Funds for Central Universities (2572019CP15).

\section{REFERENCES}

[1] Adegoke, F. F., Akinyemi, G. O., Ige, P. O., Ogunwande, O. A., Ogunade, J. O. (2010): Forestry Development; A recipe for the Nation's Economic Recession. - In: Popoola, L. (ed.) The Global Economic Crisis and Sustainable Renewable Natural Resources Management. Proceedings of the 33rd Annual FAN Conference, Benin City, Edo State, Nigeria. 
[2] Akindele, S. O., LeMay, V. M. (2006): Development of tree volume equations for common timber species in tropical rain forest area of Nigeria. - Forest Ecology and Management 226: 41-48.

[3] Alegria, C., Tome, M. (2011): A set of models of individual tree merchantable volume prediction for Pinus pinaster Aiton in central inland of Portugal. - European Journal of Forest Research 130: 871-879.

[4] Bailey, R. L. (1994): A Compatible Volume-Taper Model Based On the Schumacher and Hall Generalized Constant Form Factor Volume Equation. - Forest Science 40(2): 303313.

[5] Bates, D. M., Watts, D. G. (1988): Nonlinear regression analysis and its applications. Wiley, New York.

[6] Bi, H., Hamilton, F. (1998): Stem volume equations for native tree species in southern New South Wales and Victoria. - Australian Forestry 61(4): 275-286.

[7] Børset, O. (1954): Volume computation of standing aspen. - Commun Norweigan For Assoc 43: 397-447.

[8] Brooks, J. R., Wiant, H. V. Jr. (2005): Evaluating ecoregion based height-diameter relationship of five economically important Appalachian hardwood species in West Virginia. - Proceedings of the seventh annual forest inventory and analysis symposium; October 3-6, 2005; Portland, ME. Gen. Tech. Rep. WO-77. Washington, DC: U.S. Department of Agriculture, Forest Service: 237-242.

[9] Brooks, J. R., Wiant, H. V. Jr. (2008): Ecoregion-based local volume equations for Appalachian hardwoods. - Northern Journal of Applied Forestry 25: 87-92.

[10] Burkhart, H. E. (1977): Cubic-foot volume of loblolly pine to any merchantable top limit. - Southern Journal of Applied Forestry 1(2): 7-9.

[11] Castedo, F., Barrio, M., Parresol, B. R., Alvarez, J. G. (2005): A stochastic heightdiameter model for maritime pine ecoregions in Galicia (northwestern Spain). - Annals of Forest Science 62: 455-465.

[12] CEC (Commission for Environmental Cooperation) (1997): Ecological Regions of North America: Toward a common perspective. - CEC, Montreal. $71 \mathrm{p}$ and maps.

[13] Chourou, W. (2014): Development and evaluation of height-diameter models of gray pins and black spruce at the provincial and ecoregional scale of Alberta and Quebec. - Univ. of Quebec in Montreal. Master's thesis, 81p.

[14] Clutter, J. L., Fortson, J. C., Pienaar, L. V., Brister, G. H., Bailey, R. L. (1983): Timber Management: A Quantitative Approach. - Wiley, New York.

[15] Corral-Rivas, J. J., Barrio-Anta, M., Aguirre-Calderon, O. A., Dieguez-Aranda, U. (2007): Use of stump diameter to estimate diameter at breast height and tree volume for major pine species in El Salto, Durango (Mexico). - Forestry 80: 29-40.

[16] ELC Working Group (2000): The Ecoregions and Ecodistricts of Ontario. - Ecological Land Classification Program, Ont. Min. Nat. Resour., Sault Ste Marie, ON.

[17] Enzinga, G. Y., Jiang, L. C. (2019): Evaluation of region and subregion-based heightdiameter models for dahurian larch (larix gmelinii) in daxing'an mountains in china. Applied Ecology and Environmental Research 17(6): 13567-13591. http://www.aloki.hu, ISSN 15891623 (Print), ISSN 17850037 (Online).

[18] Eriksson, H. (1973): Volymfunktioner för stående träd av ask, asp, klibbal och contortatall. [Tree volume functions for ash, aspen, alder and lodgepole pine in Sweden (Fraxinus excelsior L., Populus tremula L., Alnus glutinosa (L.) Gartn., Pinus contorta Dougl. var. latifolia Engelm.)]. - Skogshögskolan, Institutionen för skogsproduktion, Stockholm. Rapporter og Uppsatser nr. 26-1973. 26p.

[19] Frelich, L. E. (2016): Temperate Coniferous Forests. - In: Gibson, D. (ed.) Oxford Bibliographies in Ecology. New York: Oxford University Press, October 2016. http://www.oxfordbibliographies.com/view/document/obo 9780199830060/ obo9780199830060-0162.xml?rskey=bkX55P\&result=67. 
[20] García-Espinoza, G. G., Aguirre-Calderón, O. A., Quiñonez-Barraza, G., AlanísRodríguez, E., De Los Santos-Posadas, H. M., García-Magaña, J. J. (2018): Taper and Volume Systems Based on Ratio Equations for Pinus pseudostrobus Lindley in Mexico. Forests 9(6): 344.

[21] Han, G., Zhang, G., Yang, W. (1998): Quantitative analysis on principle eco-climatic factors of limiting natural reforestation of Pinus sylvestris var. mongolica on sandy land. - Sci. Silvae Sin. 35: 22-27. (Google Scholar).

[22] Hills, G. A. (1959): A Ready Reference to the Description of the Land of Ontario and its Productivity. - Preliminary Report. Ontario Department of Lands and Forests, Division of Research, Maple. 142p.

[23] Hills, G. A. (1960): Comparison of forest ecosystems (vegetation and soil) in different climatic zones. - Silva Fennica 105: 33-39.

[24] Hjelm, B., Johansson, T. (2012): Volume equations for poplars growing on farmland in Sweden. - Scandinavian Journal of Forest Research 27: 561-566.

[25] Honer, T. G. (1967): Standard volume tables and merchantable conversion factors for the commercial tree species of central and eastern Canada. - Can. Dept. Forestry Rural Devel., For. Mgmt. Res. And Serv. Inst. Info. Rep. FMR-X-5.

[26] Hu, T., Sun, L., Hu, H., Weise, D., Guo, F. (2017): Soil Respiration of the Dahurian Larch (Larix gmelinii) Forest and the Response to Fire Disturbance in Daxing'an Mountains, China. - Scientific Reports 7: 2967. DOI: 10.1038/s41598-017-03325-4.

[27] Huang, S. (1999): Ecoregion-based individual tree height-diameter models for lodgepole pine in Alberta. - Western Journal of Applied Forestry 14: 186-193.

[28] Huang, S., Titus, S. J., Wiens, D. P. (1999): Comparison of nonlinear height-diameter functions for major Alberta tree species. - Canadian Journal of Forest Research 22: 12971304.

[29] Huang, S., Price, D., Morgan, D., Peck, K. (2000): Kozak's variable-exponent taper equation regionalized for white spruce in Alberta. - West J Appl For 15(2): 75-85. (Cross Ref Google Scholar).

[30] Husch, B., Beers, T. W., Kershaw Jr., J. A. (2003): Forest Mensuration. - 4th ed., John Wiley and Sons, Inc., New Jersey, USA. 443p.

[31] Jiang, L., Brooks, J. R., Wang, J. (2005): Compatible taper and volume equations for yellow-poplar in West Virginia. - Forest Ecology and Management 213: 399-409. (Cross Ref Google Scholar).

[32] Kitikidou, K., Milios, E., Radoglou, K. (2017): Single-entry volume table for Pius brutia in panted peri-urban forest. - Annals of Silvicultural Research 41(2): 74-79.

[33] Lee, D., Seo, Y., Choi, J. (2017): Estimation and validation of stem volume equations for Pinus densiflora, Pinus koraiensis, and Larix kaempferi in South Korea. - Forest Science and Technology 13: 77-82.

[34] Li, H., Zeng, W. (2016): Validation and comparison of two-variable tree volume tables for Larix spp. in different regions of China. - Scientia Silvae Sinicae 52(6): 157-162. (in Chinese).

[35] Li, F. (2019): Forest Mensuration, Beijing. - China Forestry Publishing House.

[36] Liu, J., Jiang, L. (2016): Compatible tree volume equations and heteroscedasticity for dahurian larch in different regions of Daxing'anling. - Forest Research 29(3): 317-323. (in Chinese).

[37] Malata, H., Ngulube, E. S., Missanjo, E. (2017): Site Specific Stem Volume Models for Pinus patula and Pinus oocarpa. - Hindawi International Journal of Forestry Research. Article ID 3981647.

[38] Misir, N., Misir, M. (2004): Developing double-entry tree volume table for Ash in Turkey. - Kafkas University, Artvin Faculty of Forestry 3(4): 135-144.

[39] Neter, J., Kutner, M. H., Nachtsheim, C. J., Wasserman, W. (1996): Applied linear statistical models. - McGraw-Hill, New York. 1048p. 
[40] Ogaya, N. (1968): Kubierungsformeln und Bestandesmassenformeln. - Inaugural. Doctoral dissertation, Dissertation-. Univ., Nat.-Math. Fak, Freiburg.

[41] Özçelik, R., Yavuz, H., Karatepe, Y., Gürlevik, N., Kiriş, R. (2014): Development of ecoregion-based height-diameter models for 3 economically important tree species of southern Turkey. - Turk J Agric For 38(3): 399-412. Tübitak doi: 10.3906/tar-1304-115.

[42] Özcelik, R., Karatepe, Y., Gürlevik, N., Canellas, I., Crecente-Campo, F. (2016): Development of ecoregion-based merchantable volume systems for Pinus brutia Ten and Pinus nigra Arnold in southern Turkey. - Journal of Forestry Research 27(1): 101-117.

[43] Özçelik, R., Çevlik, M. (2017): Batı Akdeniz Yöresi doğal sedir meşcereleri için hacim denklemleri. - Turkish Journal of Forestry 18: 68-86.

[44] Özçelik, R., Altınkaya, H. (2019): Comparison of tree volume equations for brutian pine stands in Eğirdir district. - Turkish Journal of Forestry 20(3): 149-156.

[45] Peng, C., Zhang, L., Liu, J. (2001): Developing and validation nonlinear height-diameter models for major tree species of Ontario's boreal forest. - Northern Journal of Applied Forestry 18: 87-94.

[46] Peng, C., Zhang, L., Zhou, X., Dang, Q., Huang, S. (2004): Developing and evaluating tree height-diameter models at three geographic scales for black spruce in Ontario. Northern Journal of Applied Forestry 21: 83-92.

[47] Pérez, D., Kanninen, M. (2003): Aboveground biomass of Tectona grandis plantations in Costa Rica. - Journal of Tropical Forest Science 15(1): 199-213.

[48] Perez, D. (2008): Growth and volume equations developed from stem analysis for Tectora grandis in Costa Rica. - Journal of Tropical Forest Science 20: 66-75.

[49] Qian, H., Yuan, X. Y., Chou, Y. L. (2003): Forest Vegetation of Northeast China. - In: Kolbek, J., Šrurtek, M., Box, E. O. (eds.) Forest Vegetation of Northeast Asia. Geobotany, vol 28. Springer, Dordrecht.

[50] Rachid Casnati, C., Mason, E. G., Woollons, R., Resquin, F. (2014): Volume and taper equations for P. teada (L.) and E. grandis (Hill ex. Maiden). - Agrociencia Uruguay 18(2): 47-60.

[51] Sakıcı, O. E., Sağlam, F., Seki, M. (2018): Single-and Double-entry volume equations for Crimean pine stands in Kastamonu Regional Directorate of Forestry. - Turkish Jounral of Forestry 19(19): 20-29.

[52] Saraçoğlu, N. (1988): Stem volume table for Alder (Alnus glutinosa Gaertn subsp. Barbata (C.A. Mey.) Yalt.). - Tr. J. Of Agriculture and Forestry 22: 215-225.

[53] SAS Institute Inc. (2002): SAS/STAT Online User's Guide, Version 9.0. - SAS Institute Inc., Cary, NC.

[54] Shuaibu, R. B., Alao, J. S. (2013): Centrality of Forestry Education in Environmental Sustainability. - In: Labode, P., Ogunsanwo, O. Y., Adekunle, V. A. J., Azeez, I. O., Adewole, N. O. (eds.) The Green Economy: Balancing Environmental Sustainability \& Livelihoods in an Emerging Economy. Proceedings of the 36th Annual Conference of Forestry Association of Nigeria (FAN) held in Uyo, Akwa Ibom State, Nigeria, pp 262267.

[55] Shuaibu, R. B. (2014): Stem Taper and Tree Volume Equations for Tectona grandis (Teak) in Agudu Forest Reserve, Nasarawa State, Nigeria. - Unpublished Thesis in the Department of Forestry and Wood Technology Submitted to School of Post Graduate Studies, Federal University of Technology Akure, in Partial Fulfilment of the Requirements for the Award of Master of Agricultural Technology, (M. Agric. Tech.) Degree in Forest Inventory and Biometrics, 112p.

[56] Shuaibu, R. B., Alao, J. S. (2016): Multiple Linear Regression Tree Stem Volume Equations for the Estimation of Merchantable Volume of Azadirachta Indica (Neem Tree) in North-West Region of Nigeria. - International Journal of Forestry and Horticulture (IJFH) 2(1): 1-10. ISSN 2454-9487. www.arcjournals.org.

[57] Spurr, S. H. (1952): Forest Inventory. - Ronald Press, New York, 476p. 
[58] Stolarikova, R., Salek, L., Zeahradnik, D., Dragoun, L., Jerabkova, L., Marusak, R., Merganic, J. (2014): Comparison of tree volume equations for small-leaved lime (Tilia cordota Mill.) in the Czech Republic. - Scandinavian Journal of Forest Research 29: 757763.

[59] Takata, K. (1958): Construction of universal diameter-height-curves. - Journal of Japanese Forest Society 40: 1.

[60] Teshome, T. (2005): Analysis of individual tree volume equations for Cupressus Lusitanica in Munessa Forest, Ethiopia. - Southern African Forestry Journal 203: 27-32.

[61] Wang, F., Letort, V., Lu, Q., Bai, X., Guo, Y., Reffye, P., Li, B. (2012): A Functional and Structural Mongolian Scots Pine (Pinus sylvestris var. mongolica) Model Integrating Architecture, Biomass and Effects of Precipitation. - PLoS ONE 7(8): e43531. doi:10.1371/journal.pone.0043531.

[62] Wang, H., Wan, P., Wang, Q., Liu, L., Zhang, G., Hui, G. (2017): Prevalence of InterTree Competition and Its Role in Shaping the Community Structure of a Natural Mongolian Scots Pine (Pinus sylvestris var. mongolica) Forest. - Forests 8(3): 84.

[63] WWF. (2012): Temperate Coniferous Forest Ecorgegions. http://wwf.panda.org/about_our_earth/ecoregions/about/habitat_types/selecting_terrestria 1_ecoregions/habitat05.cfm.

[64] WWF. (2019): Temperate Coniferous Forest Ecorgegion.

[65] Yavuz, H. (1999): Volume equations and volume tables for Black pine in Taşköprü. Turkish Journal of Agriculture and Forestry 23: 1181-1188.

[66] Zhang, W., Sheng, W., Jiang, Y., Zhou, Z., Wang, X. (1992): Classification of forest site system in China. - Forest Research 5(3): 251-262. (in Chinese).

[67] Zhang, L., Peng, C., Huang, S., Zhou, X. (2002): Development and evaluation of ecoregion-based jack pine height-diameter models for Ontario. - Forestry Chronicle 78(4): $530-538$. 